This item was submitted to Loughborough's Research Repository by the author.

Items in Figshare are protected by copyright, with all rights reserved, unless otherwise indicated.

\title{
Alternate water supply arrangements in peri-urban localities: awami (people's) tanks in Orangi township, Karachi
}

PLEASE CITE THE PUBLISHED VERSION

PUBLISHER

(c) Sage

LICENCE

CC BY-NC-ND 4.0

REPOSITORY RECORD

Ahmed, Noman, and M. Sohail. 2019. "Alternate Water Supply Arrangements in Peri-urban Localities: Awami (people's) Tanks in Orangi Township, Karachi”. figshare. https://hdl.handle.net/2134/3843. 
This item was submitted to Loughborough's Institutional Repository (https://dspace.lboro.ac.uk/) by the author and is made available under the following Creative Commons Licence conditions.

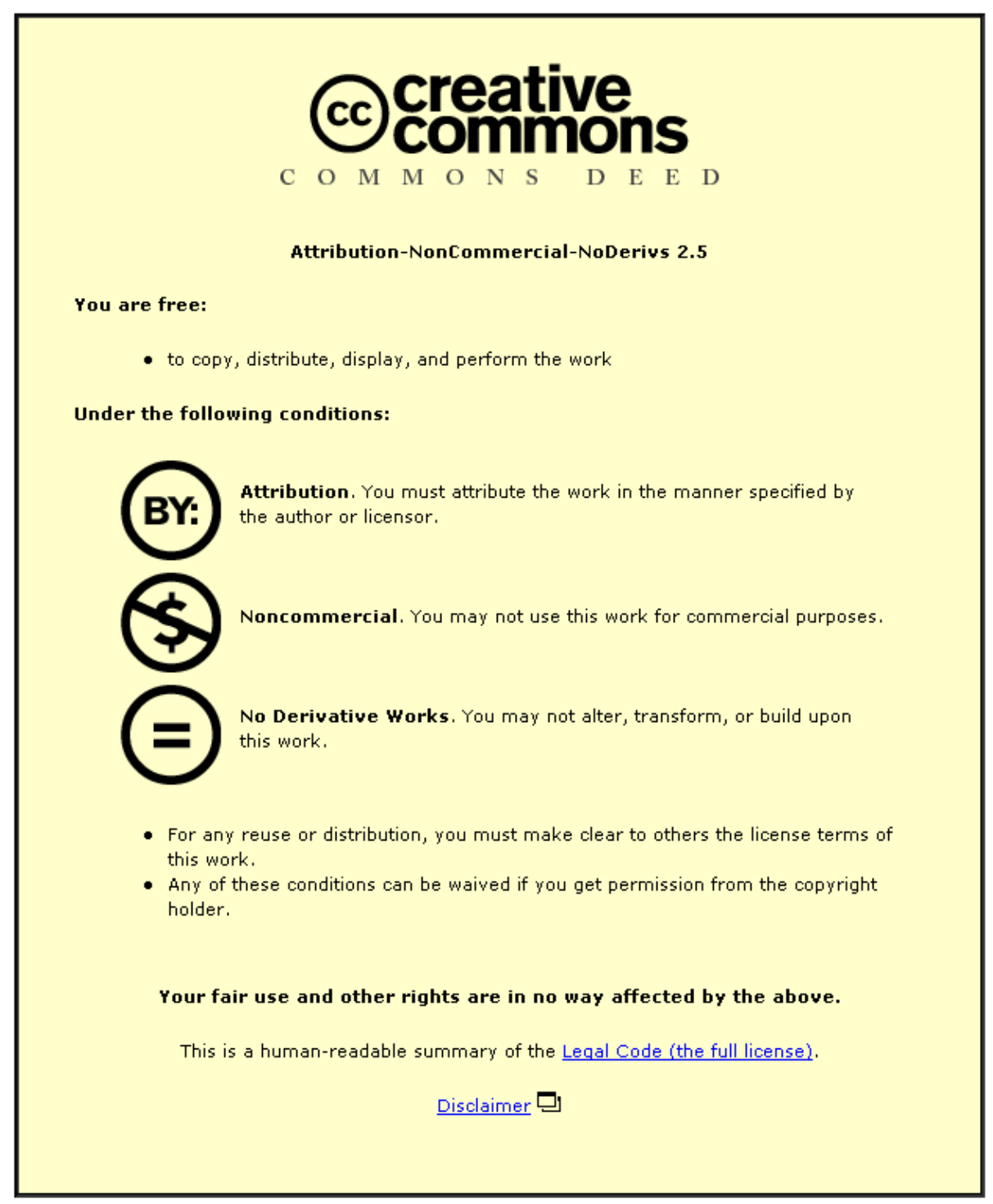

For the full text of this licence, please go to: http://creativecommons.org/licenses/by-nc-nd/2.5/ 


\title{
ALTERNATE WATER SUPPLY ARRANGEMENTS IN PERI URBAN LOCALITIES CASE OF AWAMI (PEOPLE'S) TANKS IN ORANGI TOWN, KARACHI
}

\author{
By \\ Noman Ahmed \\ Associate Professor \\ Department of Architecture and Planning \\ NED University of Engineering and Technology, Karachi \\ Dr. Muhammad Sohail \\ Senior Research Manager \\ Water, Engineering and Development Centre, \\ Loughborough University, United Kingdom
}

\section{SUMMARY}

Municipal water supply in Karachi has become grossly inadequate with reference to the user's needs and expectations. As a consequence of this inadequacy, communities suffer from the poor level of service. Peri urban locations, especially low-income settlements have very limited access to municipal water supply. Communities in these locations have to evolve alternate arrangements for acquiring the minimum quantities of water for human survival. In some situations, public sector agencies extend support in service delivery. Benefits of such support are appropriately availed when the community members organise themselves and subsequently develop working relationships with the concerned service providers. Awami tanks represent an example where water supply service was developed as a cooperative arrangement, partnership, between informally developed community organizations and public sector agencies.

This paper reviews the performance of awami tanks and explores the evolving partnerships between service providers, recipients of the service and other related stakeholders. Findings and analysis in this paper are based on documentation of 20 awami tanks in different locations in Orangi including Ghaziabad, Gulshan-e-Zia, Mansoor Nagar, Gulshan-e-Bihar and Raees Amrohi Colony. Structured feedback is obtained from concerned stakeholders such as tanker operators and owners, Karachi Water and Sewerage Board (KWSB) staff, Rangers personnel and municipal representatives. In addition, focused group meetings were held with tanker operators and area residents. Interviews were held with KWSB staff, Rangers ${ }^{1}$, elected councillors and political activists all of whom shared their views under the condition of anonymity. The findings of this paper reveal the evolution, development, operation and management of awami tanks. Analysis is done and conclusions drawn to assess the possibilities of sustainability and expansion of awami tank network.

\section{WATER SUPPLY IN KARACHI - A BACKGROUND}

\footnotetext{
${ }^{1}$ Para military force usually deployed for border security.
} 
In Pakistan, several organisational changes were implemented in the utility agencies by federal or provincial governments or under the advice of related international finance institutions over the period of time. Case of water supply utility in Karachi presents a useful example to understand this situation.

The supply and distribution of water to Karachi was handled by combination of various civic agencies in the past. The Karachi Joint Water Board, constituted in 1953, was the first entity to be assigned the task of executing the first major expansion of Karachi's water supply system from the Indus river source. Project execution was later entrusted to the Karachi Development Authority (KDA) when it was established in 1957. Distribution and retailing of treated water remained the responsibility of Karachi Metropolitan Corporation (KMC), some 22 other independent agencies, and bulk users. Over the years, the division of responsibility for production and distribution proved increasingly difficult to integrate and manage. It was subsequently decided to form a new authority to operate the entire water supply system. Thus, in 1981, the Karachi Water Management Board (KWMB) was created to take the responsibility for water distribution throughout the metropolitan area and was given enhanced powers that included distribution throughout the metropolitan area, as well as cost recovery. The operations of KWMB were never became a viable proposition as it did not have a revenue base of its own and relied on $\mathrm{KMC}$ for collection of the water rate although the tariff doubled during its existence. All this while, responsibility for maintenance of sewerage remained with the $\mathrm{KMC}^{2}$.

Appreciating the need for creation of a unified institution to handle water supply and sewerage services, the Government enacted the Sindh Local Government (Amendment) Ordinance of February 1983 which led to the creation of the Karachi Water and Sewerage Board (KWSB) within the KMC. This organizational re-structuring was done on the advice of the World Bank. It also enjoyed powers of revenue collection. Although it functioned as a totally autonomous body under the Government of Sindh Province, its policy making remained with its Board of Directors that was headed by the Mayor or Administrator of the City. In 1996, a new Act was promulgated by the provincial assembly termed as the Karachi Water and Sewerage Board Act 1996, under which the KWSB was separated from KMC. The authority to approve its annual budget was transferred to the provincial government ${ }^{3}$. Under the devolution plan currently being implemented, the Karachi City District Government shall be responsible for controlling and managing water and sanitation service. Thus KWSB shall become an organ of the city government setup. However due to some administrative reasons, the KWSB has been kept intact in its previous form, atleast till the present time ${ }^{4}$.

KWSB is the key water supply agency for the city. It arranges the production of water and supplies it to the tap of the consumers. 263 mgd of water is supplied from IndusKalri source located at a distance of $150 \mathrm{~km}$ from the city. This supply is facilitated through a comprehensive network of conduits and pumping stations. Karachi receives 20 mgd from Haleji lake source; 100 mgd from Dumlottee wells and 100 mgd from Hub

\footnotetext{
${ }^{2}$ KWSB (2000) and KWSB (1997)

${ }^{3}$ Ibid as No. 4

${ }^{4}$ For details see GoS (2001)
} 
River. All the sources are peri-urban in nature. The Hub source entirely depends upon rainfall being a seasonal stream. In dry seasons, its supply is normally discontinued as is the case nowadays. The total water demand stands at $665 \mathrm{mgd}$ as per 1998 estimates against a supply of 388 mgd. The water supply was stopped from Hub river during the same period which caused a great deal of hardship to the citizens of the westerns areas of city including Orangi Town. KWSB has planned several projects to reduce the gap of supply and demand. Cumulatively the expected demand of water shall remain $820 \mathrm{mgd}$ against a projected supply of 665 mgd in 2002-2003 (see Figure-01). There are several reasons for the continuing water shortage and poor level of service. KWSB system experiences leakage and thefts from its network up to 30-35 percent of the total supply. Leakages occur due to inappropriate management and maintenance of the system, incongruent external developments of roads/streets in the city that cause damage to the network, sub standard quality of construction and even deficiencies in the design of piping. People also break open the existing piping system to steal water either for their own consumption or for selling commercially through various vending modes. This happens along the main conduits, primary and distributory lines often in connivance with the KWSB staff members. There has been no effective leakage repair project implemented despite the fact that it has been planned and lying pending for several years. Haphazard city growth and densification has also contributed to the rise in water demand. New neighbourhood are being added to the cityscape without a corresponding addition in the water supply. Inner city areas have densified giving rise to water shortage to an acute extent. Squatter settlements have sprung up along the peri urban areas thus increasing the cost of piped supply due to extended lengths. Settlements located at the tail end of the network receive a very low level of service since a great deal of designated water quantity is already taken away, legally or illegally. The pumping procedure also falls short in effectively supplying water to tail ends of the network. Urban poor, who reside at the peripheries, mostly suffer from this situation. 


\section{FIGURE-01: PROFILE OF WATER SUPPLY IN KARACHI}

Bulk water supply (1998)

Bulk water demand (1998)

Bulk water supply (2002) Projected

Bulk water demand (2002) Projected
388 million gallons per day (mgd)

665 mgd

$605 \mathrm{mgd}$

820 mgd

\section{Water Demand (1998)}

Low income communities

63 litre/capita/day

Middle income communities

132 litre/capita/day

High income localities

335.5 litre/capita/day

\section{INVENTORY OF SERVICES}

\section{BULK WATER SUPPLY}

\section{Quantity (Water)}

1. Indus

2. Haleji

3. Dumlottee

4. Hub*

TOTAL

\section{SOURCES}

1. Dumlottee wells

2. Dumlottee Conduit

3. Haleji Conduit

4. Indus System

5. Hub System

6. Major Pumping Station

7. Filter Plants

Gharo

COD Hill

Pipri and Gharo

North East Karachi

8. Tunnel

\section{RETAIL WATER SUPPLY}

$263 \mathrm{mgd}$

20 mgd

100 mgd

100 mgd

388 mgd

1. Water Mains and Distribution Lines

2. Pumping Station and Boosting

3. Community Taps

4. Hydrants (For Tanker Supply)

5. Water Tankers

6. Reservoirs

\section{SEWERAGE SERVICES}

7 Nos

25 Miles

60 Miles

80 Miles

35 Miles

10 Nos

1. Trunk Sewers

2. Sub Mains and Lateral Sewers

3. Rising Mains

4. Treatment Plant** (20 MGD each)

5. Pumping Station

6. Automatic Sewer Cleaning Machine

7. Main/Sub Mains Sewer

8. Ejector

3360 Miles

131 Nos

3378 Nos

10 Nos

28 Nos

8 Nos

2 Nos

2 Nos

2 Nos

1 Nos

21/2 Miles
113 Miles

2700 Miles

44 Miles

2 Nos

24 Nos

12 Nos

272 Miles

11 Nos

* Hub source is fast drying up.

** A third treatment plant is being built at Mauripur, Karachi West.

Source: KWSB, 2001

The acute shortage of water and frequent break downs in supply service led various alternatives to evolve. Most of these alternatives were informal in nature. A widely practiced alternate was the privately developed water hydrants. These hydrants draw water through informally developed bore holes. They are spread in almost all the areas of city. A bore hole generates water of inferior quality usually unfit for drinking. However since the monitoring of water quality is non existing and the operation of supply takes place in connivance with the concerned government officials, therefore the supply continues unabated. Water is drawn through water motors filling water tankers which supply to designated locations. The clientele for such tanker supply includes low-income 
localities along peri urban belt of the city, other locations where water is in short supply, factories, construction sites and other miscellaneous locations. It is estimated that this mode of supply accounts for about 10 percent of the total water needs of the city ${ }^{5}$. Supply of water from informally developed sources has several repercussions. Frequent plying of tankers provides unfit water for domestic consumption which people are forced to use due to absence of alternatives. Tanker movement damages roads and streets which are not developed for movement of such vehicles. The price of such tanker loads of water is relatively low compared to those supplying fresh water from KWSB hydrants.

Water is also supplied from various other vending options in the city. There are about 5000 commercial tankers that supply to deficient areas. In addition to acquiring water from illegal hydrants, they also obtain water from KWSB hydrants under the control of Pakistan Rangers. In peak summer seasons, the tankers do a thriving business. The business potential further multiplies when KWSB piped services break down. According to officially prescribed rates, a 1200 gallons tanker is allowed to charge Rs. 250 (USD 4.2 approx); 2400 gallon can charge Rs. 500 (USD 9.5 approx) and 3600 gallons tanker can charge Rs. 800 (USD 13.795 approx). These rates are reported to double during water supply crises and break downs. It is also reported that tanker operators create artificial crisis in association with KWSB officials to expand their business potential. Occasionally commercial tankers are also made to supply water free of charge to low income settlements. Cost of such trips are borne by the government. Other modes of transportation of vended water include donkey carts which operate in areas where smallscale supplies are required. These carts fill water from leakage points and illegal hydrants. Water is also supplied through push cart vendors, manual water carriers and large under ground tank owners in communities. Most of such operations are locality bound and serve internal clientele ${ }^{6}$.

As apparent, the overall scale of operation and level of service of the KWSB is well below the desired level ${ }^{7}$. This has many reasons. Low level of tariffs, poor recovery of dues, political interference, obsolete technologies and overstaffing are some of the common ailments ${ }^{8}$. Despite the loans and technical assistance received from donor agencies, the situation did not improve. The governments tried various options to address this emerging problem. One of the possibilities was to engage the private sector in contractual agreements for provision of the services. The options considered, management contracts, leasing contracts, operating concessions, BOT (build-operatetransfer) BOO (build-own-operate), BOOT (build-own-operate-transfer) and full privatization ${ }^{9}$.

While the city scale operations of the KWSB remain under stress and await congruent improvements, some solutions at local level have evolved for the provision of service through cooperative arrangements between various stakeholders. Awami (People's) tanks

\footnotetext{
${ }^{5}$ Interview with the President, Karachi Water Tanker Association.

${ }^{6}$ As per discussion with tanker operators.

${ }^{7}$ For details, see Ahmed and Sohail (2000).

${ }^{8}$ For details in this respect, see Ahmed and Sohail (2000)

${ }^{9}$ Ibid No. 5.
} 
make one such example which were developed as a response to acute water shortage in the remote locations in Orangi Town, Karachi.

\section{AWAMI TANKS IN ORANGI TOWN - AN INTRODUCTION}

Orangi Township is situated in the Orangi hills in the western part of Karachi. It is the city's largest katchi abadi or 'squatter' settlement and covers an area of more than 8,000 acres. It has a population of about 900,000 living in 94,122 houses which people have constructed themselves with help from the informal sector. For the most part, the township was created by land-grabbers and middlemen through the illegal occupation and subdivision of state land ${ }^{10}$.

Although the Orangi Township was initiated primarily as a planned settlement and later became a katchi abadi since 1965, the piped water supply could only be provided since 1984. Geographically, Orangi lies in District West which was linked up to the Hub River source. Hub River, which is a rain fed stream, was used as a water supply source since 1982, primarily for the areas of District West ${ }^{11}$. The project was completed in three phases and was finally operational in 1995. During this period the supply was largely adequate and proved as a major cause of rapid expansion of the settlements in Orangi. However due to poor rainfall during the past three years, the water level in Hub fell down. The supply was directly affected. Due to this continuing crises it has reached to a virtual zero. At present, the areas in the former district west in general and Orangi in particular are severely hit due to absence and reduction of water supply from Hub. While there are no exact estimates available about the water need of Orangi was empirically calculated as 60 million gallons per day $(\mathrm{mgd})^{12}$. Two measures have been taken by the KWSB and city administration to tackle the shortages through tankers and upgradation/modification of pumping facilities through Indus source. The tanker service has been linked up to various formats of water provision. In the second attempt several improvements have been done. Up-gradation of North East Karachi pump house to increase the pumping capacity from $25 \mathrm{mgd}$ to $50 \mathrm{mgd}$, construction of $25 \mathrm{mgd}$ pump house at Khawaja Ajmer Nagri (of direct benefit to Orangi), inter connection of 48" and 36" dia pipes (to link up Karachi's western localities with Indus source network). Installation of new valves, sinking 12 tube wells in Orangi, Baldia, Manghopir and Surjani Town and construction of 50 water storage tanks of 10,000 gallons each in Orangi and Baldia ${ }^{13}$ were also proposed.

\footnotetext{
${ }^{10}$ Ahmed and Sohail (2001) Public Private Partnerships in Water and Sanitation Sector for the Urban Poor - Case of Karachi, Pakistan, Unpublished report, WEDC, UK. It also refers to the process of illegal sub division of land for developing informal settlements. For detailed version, refer to the earlier issues of Environment and Urbanisation.

${ }^{11}$ KDA-MPECD (1990). After the enforcement of the devolution plan on 14 August 2002, the city of Karachi is redeemed as one district. Previous spatial division of East, West, Central and Malir districts have ceased to exist.

${ }^{12}$ Cited by local KWSB staff.

${ }^{13}$ KWSB (2001). The plan to built the stipulated 50 tanks of 10000 gallons each could not materialize. The KWSB/Rangers did construct a few tanks in different locations which differed in volume. The phenomena of awami tanks viewed in this paper is somewhat different. Contrary to a conscious and programmed input to resolve a standing issue, the awami tanks were built as a quick solution to address the immediate need of water supply. Table01 provides details about the evolution, ownership and management of the tanks.
} 
Tertiary distribution pipes were laid down in Orangi on an ongoing basis and under the auspices of various programmes. During the initial period of elected local government (1979-1992), these pipelines were laid down by the area councilors through the development funds provided to them by the Karachi Metropolitan Corporation (KMC). As a consequence of such ongoing efforts, a sizable part of Orangi localities had a piped network of water even in some of the remote locations such as Ghaziabad, Gulshan-e-Zia and Gulshan-e-Bihar during the period when water supply situation was satisfactory. The shortage that emerged after the drying up of Hub source became severe during 1990s. These pressing needs of daily water supply had to be addressed on an emergency basis. The city and provincial administration decided to extend water supply through tankers to different water scarce areas in Orangi. Initially this responsibility was entrusted to the KWSB. It was advised to supply water through its own fleet of tankers as well as its contractors, during 1997-98. However the KWSB was not able to perform this function. Lack of initiative, local political influences, differences with commercial operators on supply rates etc were some of the main reasons for this situation. As the situation was becoming tense almost leading to water riots, the administration later decided to entrust this responsibility to Pakistan Rangers which was also called in to aide the civil administration in restoring law and order in the city.

The Rangers carried out a survey of the affected areas. One of the conclusions drawn from the survey was that the water supply could be facilitated effectively if some area nodal points are developed to store and distribute the water supplied through the tankers. It was also found that the political influence on the routines of supply need to be curbed which Rangers were able to do due to their military clout. In this study, the Rangers found out few locations where small scale community tanks were existing. In other areas, the mosques and churches had underground tanks already constructed. The respective mosque or church committees agreed to allow the use of their underground tanks as communal water supply reservoirs. In addition to these two types, there were new tanks constructed either by people through self-help or by the Rangers ${ }^{14}$ (see Table-01).

TABLE-01

AWAMI TANKS: EVOLUTION, OWNERSHIP AND MANAGEMENT ${ }^{15}$

\begin{tabular}{|c|c|c|c|c|}
\hline No. & Location & Built by & Management & Ownership \\
\hline 01. & Gulshan-e-Zia & $\begin{array}{l}\begin{array}{l}\text { Built in } 1989 \text { by the } \\
\text { Rangers } \\
\text { contribution } \\
\text { (through } \\
\text { people/mosque) }\end{array} \\
\end{array}$ & $\begin{array}{l}\text { A community elder } \\
\text { and Imam (prayer } \\
\text { leader) runs it. }\end{array}$ & $\begin{array}{l}\text { Owned by the } \\
\begin{array}{l}\text { Madrassah } \\
\text { seminary) } \\
\text { (local } \\
\text { mosque. }\end{array}\end{array}$ \\
\hline 02. & Gulshan-e-Zia & $\begin{array}{l}\text { Built in } 1990 \text { by the } \\
\text { people through self help. }\end{array}$ & $\begin{array}{l}\text { A community elder } \\
\text { manages it on behalf } \\
\text { of the community; } \\
\text { Rangers monitor } \\
\text { supply through the } \\
\text { tankers. }\end{array}$ & $\begin{array}{l}\text { Owned by the } \\
\text { people/graveyard } \\
\text { committee. }\end{array}$ \\
\hline
\end{tabular}

\footnotetext{
${ }^{14}$ Interview with Rangers Officers incharge of water supply in Orangi, 2001.

${ }^{15}$ This table is based on the study of the 22 awami tanks included in the study that was done in 2000 by the authors.
} 


\begin{tabular}{|c|c|c|c|c|}
\hline No. & Location & Built by & Management & Ownership \\
\hline 03. & Gulshan-e-Zia & $\begin{array}{l}\text { Built in } 1982 \text { by the } \\
\text { people. }\end{array}$ & $\begin{array}{l}\text { Runs on self help by } \\
\text { the people of the area. }\end{array}$ & $\begin{array}{l}\text { Owned by the } \\
\text { people. }\end{array}$ \\
\hline 04. & Gulshan-e-Zia & $\begin{array}{l}\text { Built ten year's before } \\
\text { through the help of } \\
\text { Thalawala. }\end{array}$ & $\begin{array}{l}\text { Thalawala } \\
\text { building component } \\
\text { manufacturer) is } \\
\text { responsible. }\end{array}$ & Thalawala. \\
\hline 05. & Gulshan-e-Zia & $\begin{array}{l}\text { Before } 11 \text { year it was } \\
\text { made by Mohalla (sub } \\
\text { neighbourhood) } \\
\text { committee through } \\
\text { contributions. }\end{array}$ & $\begin{array}{l}\text { Mohalla community is } \\
\text { responsible for its } \\
\text { operation. }\end{array}$ & $\begin{array}{l}\text { Mohalla } \\
\text { committee. }\end{array}$ \\
\hline 06. & Gulshan-e-Zia & $\begin{array}{l}\text { Before ten years by the } \\
\text { Mosque Committee. }\end{array}$ & Mosque committee. & $\begin{array}{l}\text { Mosque } \\
\text { Committee. }\end{array}$ \\
\hline 07. & Gulshan-e-Zia & $\begin{array}{l}\text { Before } 12 \text { year, the block } \\
\text { maker volunteered the } \\
\text { construction. }\end{array}$ & Mohalla committee. & $\begin{array}{l}\text { Mohalla } \\
\text { committee. }\end{array}$ \\
\hline 08. & Gulshan-e-Zia & $\begin{array}{l}\text { Before } 2 \text { years it was built } \\
\text { by the Mosque } \\
\text { committee. }\end{array}$ & Mosque committee. & $\begin{array}{l}\text { Mosque } \\
\text { committee. }\end{array}$ \\
\hline 09. & Ghaziabad & $\begin{array}{l}\text { This tank was made by } \\
\text { Mosque committee } 10 \\
\text { years ago. }\end{array}$ & Mosque committee. & $\begin{array}{l}\text { Mosque } \\
\text { committee. }\end{array}$ \\
\hline 10. & $\begin{array}{l}\text { Muslim } \\
\text { Maywati } \\
\text { Colony, } \\
\text { Ghaziabad }\end{array}$ & $\begin{array}{l}11 \frac{1}{2} \text { years } \\
\text { established by Mosque } \\
\text { committee. }\end{array}$ & Mosque committee. & $\begin{array}{l}\text { Mosque } \\
\text { committee. }\end{array}$ \\
\hline 11. & Ghaziabad & $\begin{array}{l}\text { Mosque committee build } \\
\text { this tank } 1 \text { year before. }\end{array}$ & Mosque committee. & $\begin{array}{l}\text { Mosque } \\
\text { committee. }\end{array}$ \\
\hline 12. & Ghaziabad & $\begin{array}{l}\text { One year before it was } \\
\text { established. }\end{array}$ & $\begin{array}{l}\text { Shopkeeper } \\
\text { responsible. }\end{array}$ & Shopkeeper. \\
\hline 13. & $\begin{array}{l}\text { Christian } \\
\text { Colony, } \\
\text { Ghaziabad }\end{array}$ & $\begin{array}{l}\text { A local philanthropist } \\
\text { made this tank one year } \\
\text { before. }\end{array}$ & $\begin{array}{l}\text { Local philanthropist } \\
\text { and with two helpers. }\end{array}$ & $\begin{array}{l}\text { Local } \\
\text { philanthropist. }\end{array}$ \\
\hline 14. & $\begin{array}{l}\text { Christian } \\
\text { Colony, } \\
\text { Ghaziabad }\end{array}$ & $\begin{array}{l}\text { Local philanthropist made } \\
\text { it } 10 \text { year before. }\end{array}$ & $\begin{array}{l}\text { Local philanthropist is } \\
\text { responsible. }\end{array}$ & $\begin{array}{l}\text { Local } \\
\text { philanthropist. }\end{array}$ \\
\hline 15. & $\begin{array}{l}\text { Muslim } \\
\text { Colony, } \\
\text { Ghaziabad }\end{array}$ & $\begin{array}{l}\text { Built eight years ago by } \\
\text { the government. }\end{array}$ & Mosque committee. & $\begin{array}{l}\text { Mosque } \\
\text { committee. }\end{array}$ \\
\hline 16. & Yaqoobabad & $\begin{array}{l}\text { It was made one year } \\
\text { before by community } \\
\text { contributions. }\end{array}$ & Community elders. & Community elders. \\
\hline
\end{tabular}




\begin{tabular}{|c|l|l|l|l|}
\hline No. & Location & \multicolumn{1}{|c|}{ Built by } & \multicolumn{1}{|c|}{ Management } & \multicolumn{1}{|c|}{ Ownership } \\
\hline 17. & Yaqoobabad & $\begin{array}{l}\text { Established } 4 \text { months } \\
\text { before by few community } \\
\text { elders. }\end{array}$ & Community elders. & Community elders. \\
\hline 18. & Mansoor Nagar & $\begin{array}{l}\text { Established } 6 \text { month } \\
\text { before by Rangers. }\end{array}$ & Mohalla committee. & $\begin{array}{l}\text { Mohalla } \\
\text { committee. }\end{array}$ \\
\hline 19. & Mansoor Nagar & $\begin{array}{l}\text { Made 7 years before } \\
\text { through the help of } \\
\text { Orangi Pilot Project. }\end{array}$ & $\begin{array}{l}\text { Local philanthropist is } \\
\text { responsible. }\end{array}$ & $\begin{array}{l}\text { Local } \\
\text { philanthropist. }\end{array}$ \\
\hline 20. & Mansoor Nagar & $\begin{array}{l}\text { Built by Mohalla } \\
\text { committee in 1983. }\end{array}$ & Mohalla committee. & $\begin{array}{l}\text { Mohalla } \\
\text { committee. }\end{array}$ \\
\hline 21. & Mansoor Nagar & $\begin{array}{l}\text { Made up in 1990 by a } \\
\text { community } \\
\text { philanthropist. }\end{array}$ & $\begin{array}{l}\text { Community } \\
\text { philanthropist. }\end{array}$ & $\begin{array}{l}\text { Community } \\
\text { philanthropist } \\
\text { (allowed his house } \\
\text { tanks to be utilized } \\
\text { for community } \\
\text { benefit). }\end{array}$ \\
\hline 22. & Mansoor Nagar & $\begin{array}{l}\text { Before 14 years it was } \\
\text { established Hakim Khan } \\
\text { made it for the mosque. }\end{array}$ & Mosque committee. & $\begin{array}{l}\text { Mosque } \\
\text { committee. }\end{array}$ \\
\hline
\end{tabular}

Source: Ahmed and Sohail (2001) Public Private Partnerships in Water and Sanitation Sector for the Urban Poor - Case of Karachi, Pakistan, Unpublished report, WEDC, UK.

Awami Tanks (or people's tanks) can be defined as the underground water tanks built to store and distribute water to the local community members. They exist in several formats. The underground tanks that are normally constructed in neighbourhood mosques or churches have also been used as awami tanks. This was one of the earlier options of community based water storage and distribution in situations of shortages or ruptures in supply. Other public locations such as grave yards or common neighbourhood open spaces have been utilized for such tanks through a purpose built format of construction. In few cases, residents have allowed the use of their house tanks as awami tanks for the benefit of other community residents. However this has been possible where the size of the tank was large enough to store 1-2 tanker loads of water - approximately 6000 gallons. In addition to these types which were built by the people through their own resources, the Rangers have also built awami tanks on public open spaces. Awami tanks have been developed in Orangi Town in Ghaziabad, Gulshan-e-Zia, Gulshan-e-Bihar, Mansoor Nagar, Yaqoobabad, Chisti Nagar, Rais Amrohi Colony and adjoining areas. Recently it has been reported that awami tanks are also developed in Baldia and Surjani Towns in Karachi. Total number of awami tanks is not known nor mentioned in any specific record with Rangers/KWSB.

Water is supplied to awami tanks through commercial water contractors enlisted with KWSB/Pakistan Rangers. The contractors fill the tankers from authorized hydrants and supply the water to designated awami tanks according to frequency decided by the Rangers. Water and transportation charges for this supply is reported to be paid by Pakistan Rangers. After the supply is received in awami tanks, people acquire water from 
these tanks in canister and other vessels. The water is transported to the houses manually. Each awami tank is meant to serve its own area residents which are informally defined.

\section{FINDINGS}

\subsection{Need for Awami Tanks}

The findings showed that the need of awami tanks evolved due to several reasons. One, the supply could not be facilitated through the piped network due to the overall shortage of water. Two, even in areas where some piped supply was released, it was grossly inadequate to meet the domestic needs. In some cases, such piped supply was reported to be contaminated due to mixing of sewerage water with normal water. Three, in areas where piped supply was abandoned for some times, water pipes were either stolen or vandalized. The pipes were also damaged when some residents took illegal connections or broke open the joints in a bid to obtain more water than sanctioned for each house. This further reduced the chances of immediate resumption of piped supply which could only be restored after appropriate repairs. And four, to meet their respective daily needs, a sizable number of households acquired water supply from commercial tankers from illegal hydrants. This water was not fit for drinking though it was utilized for several other domestic chores such as washing clothes, bathing, washing utensils or in the toilet. Thus there remained a pressing need for drinking water supply.

\subsection{Management and Operation}

As mentioned earlier, tanker supply from designated KWSB hydrants to the awami tanks is managed and monitored by the Rangers. The Rangers personnel maintains list of all the tankers that ply on different routes; prepare route maps; issue payments to the tanker operators on the basis of actual supply; respond to emergency situations regarding supply and attend to the complains lodged by area residents.

Management of supply from the awami tanks to the residents is undertaken by mosque committee, neighbourhood committee or group of area elders who are given this task with the consent of the area residents. These committees or groups maintain record of tanker supply including frequency and quantities; manage the distribution; organise maintenance or repairs and liaise with Rangers in case of lodging a complaint or related matters. It may be noted that the area residents have to jointly raise small funds to undertake any repair that may arise.

Awami tanks receive water at varying frequencies and quantities. In some cases, water is supplied twice a week, while in the others it is once a week or even once in a fort night. Usually at least one tanker load of 1200 gallons is provided. In acute shortages, one tanker load of water is divided into two or three awami tanks. During the day time, the supply to the awami tanks remains scarce. The supply normally comes in the evening or night time. The water is distributed after receiving the tanker supply. People come to the tank with their vessels. Water is either lifted up manually using a rope and pale or a tap. In some mosques, the lifting of water is done through pumping motors. The motors pull the water up which is then filled in the vessels. In very few cases, the water is rationed by 
the management group. Usually people fill the water according to drinking need. Water from awami tanks could not fulfil other needs due to its limited quantities. Majority of the people interviewed were of the view that the supply of water through awami tanks is temporary. They wished that the pipelines should be fully repaired and water supplied regularly.

\section{ANALYSIS}

With the hilly terrain of Orangi Town, a smooth piped supply of water is a difficult task which requires technical review for determining the options of pumping. Vending or similar improvised solutions such as awami tanks are the only available option atleast in the prevailing circumstances due to anticipated high infrastructure costs. It was found that most of the underground water pipes have been damaged and require massive repairs before any utilization. Thus, even if the adequate water becomes available through some source for supply through pipes, it cannot be provided before repairs. Thus people will have to rely on the awami tanks or alternatives of water vending.

Water hydrants were under a great deal of political pressure. However Rangers have been able to discipline the supply format which has worked for the mutual benefit of all the communities concerned. Rangers were supplying the water without any charge as the cost was borne by the government. Majority of the people, linked to awami tanks, are satisfied with its supply. It is feared that when the Rangers will be called back, the existing system of water supply through awami tanks will be directly affected. People's fears are based on the assumption that after Rangers, local political groups will be able to exercise their influences to supply water only to their areas of choice leaving the general public unattended.

Water supply through awami tanks normally takes place during the night time. Tanker movement becomes convenient due to less traffic. Also, this depends on the cycle of supply from city sources to the hydrants. Night supply causes problem to those families who do not have a male member in the house capable to lift the water from the awami tank to the house. It also causes a general inconvenience to the residents who are forced to keep awake for long hours in the night waiting for the tankers to arrive. It is especially a problem for those veil observing women folk who find it difficult to physically carry the pales full of water to their homes in the night. The frequencies of supply were usually found independent of the need of water. It was due to the reason that the bulk water supply to the hydrant depended greatly on the overall water supply situation of the city. Thus the scarcity at the city scale affected the supply procedure to the awami tanks. People whose houses are far from awami tanks have many complains regarding immense physical labour needed to carry water. Also, water supplied from awami tanks can barely meet the drinking water needs.

Ownership of the tanks, where belongs to the people, leads to appropriate maintenance and upkeep. When people build this component of infrastructure through their own resources, they make sure that it is properly kept and looked after. In contrast, the government built tanks were poorly managed as the people do not own them. These tanks 
often become victims of vandalism as people do not tend to safeguard them. The study also revealed that many tanks were poorly constructed. This caused water losses even though the duration of storage did not exceed a day in several cases.

Private tankers operate in these areas. The private tankers become a necessity as the supply of water through the tankers of Rangers and awami tanks is often limited. This water is obtained from illegally developed hydrants/boreholes. Such water is unfit for drinking although it is supplied to consumers without any kind of restraint. This becomes a source of disease and hazard for public health. However, due to acute shortage, people become forced to purchase such water at exaggerated prices. Awami tanks become a necessity in some areas where piped water supply is relatively better. Often the water pipes lie in juxtaposition of sewerage pipes. Due to seepage, the water gets contaminated. Thus, in such locations, poor quality of water forces them to purchase/obtain atleast drinking water from some external source.

Awami tanks are perceived as a cooperative arrangement by the people, not a commercial solution. However, as the quantities of water supplied are bare minimum, not even compatible to the basic human needs, people desire an upliftment in the level of service. They consider piped water supply the only sustainable mode on the basis of common perceptions. Since awami tanks have developed as a near pilot initiative, they are perceived as a temporary solution to an existing problem.

\section{CONCLUSIONS AND RECOMMENDATIONS}

Study and analysis of awami tank show that the communities, with support from the government agencies, can generate cooperative action for addressing their basic needs. It is a significant aspect to note that despite the acute shortage of water in Orangi Town, low economic status of the households and an overall feeling of desperation, there has been no communal conflict in the routine operation of awami tanks. However the relatively sparse frequency of water supply to the awami tanks has adversely affected the possibility of its indigenous expansion. Communities are concerned about the inavailability of water from the source itself. Besides, the assumption that piped water supply will be generated soon often retards the extension of awami tank operations. From the overall water supply scenario of the city in general and Orangi in particular, it has become clear that piped water supply for Orangi in the near future will remain grossly inadequate. Appropriate solutions, with optimum capacity to deliver, have to be tried, tested and replicated. It is also obvious from the study that government alone cannot deliver the services due to the limited capacity to address the problems. It will have to rely on a mechanism of partnership that evolves from the people's initiative and then sustains towards permanence.

Awami tanks offer an important case study in water supply options that have developed and sustained in the low-income communities. They can be greatly improved by taking some appropriate measures. The design and construction of awami tanks need to be improved. At present, they are built through cement block construction without any plastering and waterproofing. Due to this reason, the water is lost due to seepage. Low 
cost techniques for constructing stable tanks can be created. In order to resolve the problems of awami tanks, water provision should be done daily or once in two days. The quantity of water should be adequate to meet the needs. By using motors or simple manual pumps, the efficiency of supply can be greatly improved. Plastic or rubber pipes may be used where taps/motors are available to supply water directly to houses. The communities can negotiate a mechanism with KWSB for regular supply of water on payment of corresponding charges, which obviously will be much less than the commercial tankers. This alone will enhance the performance of awami tanks to a sizable extent. The reality about non-performance of piped water supply need to be clearly communicated to the people of Orangi by the authorities and elected representatives so that they can contemplate about options and survival strategies. Unfortunately they are not willing to do so in order to keep their political and administrative hold on the communities.

\section{REFERENCES}

Ahmed N. and

Sohail M. (2000)

'Privatisation of KWSB - An Analysis', City Press, Karachi.

ADB (1994)

Pakistan Urban Sector Profile, Final Report, Manila

ADB (1993)

Mega City Case Study - Karachi, Draft Report (Volumes 1\&2), Asian Development Bank, Karachi.

Bengali, K.et.al (1990) 'Issues in Municipal Finance and Management. The Case of Karachi’ in Regional Development Dialogue, Vol. 10, No. 1.

Barbieux, C. (1998) 'Privatising in the Public Interest' in UNCHS DEBATE, Vol. 4 No. 3.s.

Brisco. J (1997)

Managing Water as an Economic Good: Rules for Reformers, Keynote Paper the International Committee on Irrigation and Drainage Conference on Water as our Economic Good, Oxford.

Banque Paribas et.al. (1997) Private sector participation in KWSB, Strategy Report, Banque Paribas, 1997.

Cheghtai, T. (1998)

'Tanker Mafia - Earning Rs. 2.5 Million Daily’ in Jafakash Monthly (in Urdu), Karachi.

GoS (2001)

Sindh Local Government Ordinance, Government of Sindh, Karachi.

Hasan, A. (1992)

Manual for Rehabilitation Programmes for Informal Settlements Based on the Orangi Pilot Project Model, Karachi: OPP-RTI. 
Kamal, A. (1996)

KDA-MPECD (1990)

KDA-MPECD (1973)

KWSB (1997)

KWSB, 2001

2000

Mackintosh A.C. and Yniguez, C.E. (1997)

UNCRD (1999)

WEDC (1998)

World Bank
'Story of Karachi’ (Volumes I\&II), Aaj, Karachi.

Karachi Development Plan - 2000 Final Draft Report, Karachi Development Authority, Karachi.

Karachi Development Plan - 1973-1985, Final Draft Report, Karachi Development Authority, Karachi.

Karachi - Water Supply and Sewerage - Basic Facts, Karachi Water and Sewerage Board, Karachi.

Karachi Water and Sewerage Board: Basic Facts - KWSB, Karachi.

Karachi Water and Sewerage Broad: Basic Facts - 2000, KWSB, Karachi.

Second Water Utilities Data Book, Manila: Asian Development Bank.

'Water Utility in Asian Cities', Data Book United Nations Centre for Regional Development Nagoya.

Preprints of the $24^{\text {th }}$ International Conference, Islamabad.

A strategy for introducing private sector participation in Urban Water Supply and wastewater services in Pakistan (Internal circulation). 